\title{
Polskie opracowanie krótkiej wersji Skali poczucia skuteczności nauczycielskiej (TSES) Tschannen-Moran i Woolfolk Hoy ${ }^{1}$
}

\author{
Piotr Adam Hreciński \\ piotradam@tlen.pl
}

Teachers' Sense of Efficacy Scale (TSES) autorstwa Tschannen-Moran i Woolfolk Hoy jest narzędziem umożliwiającym pomiar przekonania o własnej skuteczności nauczycielskiej w wymiarze motywowania uczniów, nauczania i kierowania klasą. Metoda ta posiada dobre ugruntowanie w społeczno-poznawczej teorii Bandury. Zaprezentowane $\mathrm{w}$ niniejszym artykule polskie tłumaczenie krótkiej wersji tej skali odzwierciedla trójczynnikową strukturę oryginału i posiada satysfakcjonujące właściwości psychometryczne. Mimo pewnych słabości narzędzie to wydaje się być przydatną miarą $\mathrm{w}$ badaniach psychologicznych podejmowanych wśród polskich nauczycieli.

\section{Wprowadzenie teoretyczne}

Przekonanie o własnej skuteczności (self-efficacy) stanowi kluczowy konstrukt w społeczno-poznawczej teorii Bandury (1977). Odnosi się on do przeświadczenia osoby o jej zdolności do działania, wymaganego dla uzyskania określonego celu. Kwestią odrębną pozostaje natomiast osąd dotyczący tego, czy dana aktywność zakończy się sukcesem albo porażką. Znaczenie ważniejsza jest bowiem ocena samych możliwości podjęcia określonej czynności. To od niej zależy, czy osoba w ogóle spróbuje poradzić sobie z konkretnymi wyzwaniami. Zdaniem autora koncepcji ludzie obawiają się i unikają zachowań, które w ich mniemaniu przekraczają posiadane przez nich zdolności poradzenia sobie. Chętnie zaś angażują się w działania, co do których są przekonani, że potrafią je wykonać.

Według Bandury (1977) przekonanie o własnej skuteczności rozwija się na podstawie osobistych doświadczeń w podejmowanych czynnościach, obserwacji modelu, perswazji słownej ze strony innych osób oraz odczucia swoich stanów fizjologicznych i afektywnych

\footnotetext{
${ }^{1}$ Skala została opracowana w ramach rozprawy doktorskiej pt. „Psychospołeczne korelaty wypalenia zawodowego u nauczycieli religii", napisanej w Instytucie Psychologii KUL pod kierunkiem dr hab. Stanisławy Ewy Tucholskiej.
} 
POLSKIE OPRACOWANIE KRÓTKIEJ WERSJI SKALI POCZUCIA SKUTECZNOŚCI NAUCZYCIELSKIEJ (TSES) TSHANNEN-MORAN I WOOLFOLK HOY

w kontekście określonej aktywności. Zgodnie z założeniami teorii społeczno-poznawczej dotyczy ono przede wszystkim konkretnych działań i chociaż podlega pewnej generalizacji, najtrafniej jest je odnosić do określonych obszarów funkcjonowania. Stąd można mówić o przekonaniu o własnej skuteczności w radzeniu sobie z zadaniami charakterystycznymi dla roli ucznia, członka rodziny lub pracownika określonego zawodu. W przypadku nauczycieli opisywany konstrukt może dotyczyć takich umiejętności jak: przekazywanie wiedzy, organizacja pracy uczniów w klasie, utrzymywanie dyscypliny i tworzenie pozytywnego klimatu w szkole, angażowanie wychowanków niechętnych do nauki, współpraca z innymi pedagogami oraz z rodzicami, radzenie sobie ze zmianami wprowadzanymi do programów nauczania, dostosowywanie wymagań programowych do możliwości określonych uczniów, wpływ na decyzje podejmowane w szkole, stosowanie pomocy dydaktycznych itp. (Bandura 1997: za: Tschannen-Moran, Woolfolk Hoy, 2001).

Przekonanie o własnej skuteczności nauczycielskiej może być ujmowane jako ocena posiadanych przez pedagoga zdolności do osiągania pożądanych rezultatów własnej pracy dydaktycznej i wychowawczej, pomimo napotykanych trudności. Nauczyciele wysoko oceniający własne umiejętności zawodowe osiągają lepsze wyniki swoich działań, są bardziej zorganizowani, chętnie korzystają $\mathrm{z}$ nowych metod nauczania, okazują się wytrwalsi w przypadku trudności, są wyrozumiali wobec błędów uczniów i potrafią poświęcać im więcej czasu, gdy to konieczne. Wykazują także większy entuzjazm w wykonywaniu swoich obowiązków (Tschannen-Moran, Woolfolk Hoy, 2001).

Tschannen-Moran i Woolfolk Hoy (2001), uwzględniając dorobek wcześniejszych badaczy, podjęły próbę stworzenia własnego, współczesnego narzędzia pomiarowego, odpowiadającego w najwyższym stopniu założeniom koncepcji własnej skuteczności. W efekcie tych działań skonstruowano dwie wersje Skali poczucia skuteczności nauczycielskiej (Teachers' Sense of Efficacy Scale - TSES). W niniejszym artykule zaprezentowano prace związane z thumaczeniem krótszej wersji tego kwestionariusza na język polski.

\section{Badania wlasne}

\section{Metoda}

Przekonanie o własnej skuteczności nauczycielskiej opisywane jest przez TschannenMoran i Woolfolk Hoy (2001) jako dokonywana przez pedagoga ocena własnych zdolności do osiągania pożądanych rezultatów w angażowaniu i kształceniu uczniów. Zaproponowana 
POLSKIE OPRACOWANIE KRÓTKIEJ WERSJI SKALI POCZUCIA SKUTECZNOŚCI NAUCZYCIELSKIEJ (TSES) TSHANNEN-MORAN I WOOLFOLK HOY

przez autorki Skala poczucia skuteczności nauczycielskiej (TSES) umożliwia pomiar tego konstruktu wymiarze motywowania uczniów (engagement) ${ }^{2}$, nauczania (instruction) i kierowania klasą (management). Narzędzie to odpowiada zatem wskazaniom Bandury (1997, za: Tschannen-Moran, Woolfolk Hoy, 2001), zgodnie z którymi miara poczucia własnej skuteczności w zawodzie nauczyciela powinna ujmować ten konstrukt w sposób wielowymiarowy, odnosząc się do różnych aspektów pracy pedagoga.

Kwestionariusz TSES występuje w dwóch wersjach: dłuższa składa się z 24, natomiast krótsza z 12 pozycji testowych. Każdy z trzech wymiarów poczucia skuteczności reprezentowany jest, zależnie od wersji, przez 8 lub 4 pytania, na które badani odpowiadają przy pomocy 10-stopniowej skali. Miara poziomu przekonania o własnej skuteczności w każdym wymiarze obliczana jest jako średnia arytmetyczna wyników uzyskanych w itemach tworzących poszczególne dymensje. Uwzględniając wyniki we wszystkich podskalach istnieje też możliwość wyliczenia wyniku ogólnego dla poczucia skuteczności nauczycielskiej, traktowanej w tym przypadku jako czynnik drugiego rzędu ${ }^{3}$. Anglojęzyczna wersja kwestionariusza posiada bardzo dobre współczynniki zgodności wewnętrznej. Wyznacznik $\alpha$ Cronbacha wyliczony w próbie 410 nauczycieli pracujących w USA dla podskal wersji dłuższej zawiera się w granicach $0,87-0,90$, dla wyniku ogólnego równa się 0,94 ; natomiast dla wersji krótszej kwestionariusza wynosi odpowiednio 0,81-0,86 i 0,90.

Psychometryczne właściwości 12-itemowej wersji TSES poddali weryfikacji Klassen, Bong, Usher, Chong, Huan i in. (2009) w pięciu różnych krajach: Kanadzie, na Cyprze, Korei, Singapurze i USA. Konfirmacyjna analiza czynnikowa (CFA) wykonana w każdej próbie wykazała lepsze dopasowanie w przypadku modelu z trzema podskalami niż rozwiązania jednoczynnikowego. Przyjęta w wersji oryginalnej struktura skali uzyskała akceptowalne wskaźniki adekwatności w grupach wypełniających angielską wersję kwestionariusza. W przypadku tłumaczenia na język grecki wyniki CFA okazały się możliwe do akceptacji po uwzględnieniu korelacji błędów dla dwóch zmiennych jawnych w testowanym modelu. Podob-

\footnotetext{
${ }^{2}$ Choć dosłowny przekład oryginalnej nazwy zastosowanej dla tego wymiaru brzmiałby angażowanie, zdecydowano się na użycie terminu motywowanie. Wydaje się bowiem, że takie określenie jest bliższe terminologii stosowanej przez polskich nauczycieli oraz lepiej w języku polskim opisuje reprezentujące ten wymiar pytania.

${ }^{3}$ Oryginalna wersja TSES może być stosowana także w badaniach prowadzonych wśród osób odbywających praktyki w szkole, w ramach przygotowania do zawodu nauczyciela. W takiej sytuacji autorki skali zalecają jednak korzystanie z wyniku ogólnego, ponieważ struktura trójczynnikowa $w$ tej grupie badanych nie jest jednoznacznie odwzorowana (Tschannen-Moran, Woolfolk Hoy, 2001; zob. też: Fives, Buehl, 2010).
} 
POLSKIE OPRACOWANIE KRÓTKIEJ WERSJI SKALI POCZUCIA SKUTECZNOŚCI NAUCZYCIELSKIEJ (TSES) TSHANNEN-MORAN I WOOLFOLK HOY

ne rozwiązanie nie przyniosło pożądanej poprawy wskaźników dopasowania dla koreańskiej wersji skali. Trafność teoretyczna trójczynnikowego modelu TSES, choć została w zadowalający sposób potwierdzona dla angielskiej wersji językowej testu, w przypadku jego tłumaczeń wymaga dalszej weryfikacji.

Pierwotną strukturę inwentarza oraz jego wysoką rzetelność wewnętrzną potwierdzili również Fives i Buehl (2010) w badaniach nauczycieli amerykańskich. Wyodrębnione przez nich czynniki miały jednak inną niż w wersji oryginalnej kolejność, a w przypadku jednej z pozycji testowej uzyskano wysokie ładunki czynnikowe w obrębie dwóch składowych głównych. Trudności z klasyfikacją jednego z pytań kwestionariusza zauważyli także Klassen i Chiu (2011), badając nauczycieli kanadyjskich. Generalnie potwierdzono jednak trójczynnikową strukturę TSES oraz wysoką zgodność wewnętrzną skal. Treść pytań dłuższej i krótszej wersji skali wraz z opisem jej własności psychometrycznych można znaleźć w pracy Tschannen-Moran i Woolfolk Hoy (2001) oraz pod adresem prowadzonej przez jedną z autorek kwestionariusza strony internetowej: http:// wmpeople.wm.edu/site/page/mxtsch.

\section{Procedura badania}

Podejmując się zadania opracowania polskiej, skróconej wersji TSES poproszono o zgodę na jego tłumaczenie. Ponieważ żadna z autorek skali nie rekomendowała konkretnej procedury przekładu, przyjęto jako zasadę utrzymanie wierności językowej wobec oryginału, przyznając jednakże priorytet zachowaniu znaczenia poszczególnych pozycji. Odpowiadało to metodzie tłumaczenia testów, określanej mianem translacji. Respektuje ona wierność tłumaczenia, umożliwiając jednak wprowadzanie zmian wobec sformułowań nieadekwatnych w danej kulturze na rzecz stosowanych w niej powszechnie odpowiedników (Drwal, 1995). Biorąc pod uwagę te założenia, cztery osoby (trzech psychologów i pedagog), ze znajomością języka angielskiego, dokonały niezależnych tłumaczeń oryginalnej wersji TSES. Efekty ich pracy zostały poddane dyskusji, w wyniku której opracowano wstępną propozycję poszczególnych itemów. Sporządzona w ten sposób wersja skali stała się przedmiotem konsultacji z dwójką aktywnych zawodowo nauczycieli (polonistki oraz nauczyciela przedmiotów ścisłych: chemii i informatyki) a także osoby prowadzącej zajęcia z metodyki pracy umysłowej oraz z dydaktyki ogólnej i szczegółowej dla studentów przygotowujących się do pracy pedagogicznej.

Po uzyskaniu pozytywnej opinii na temat zrozumiałości pytań kwestionariusza i poprawności użytych w przekładzie terminów technicznych stosowanych w polskim szkolnic- 
POLSKIE OPRACOWANIE KRÓTKIEJ WERSJI SKALI POCZUCIA SKUTECZNOŚCI NAUCZYCIELSKIEJ (TSES) TSHANNEN-MORAN I WOOLFOLK HOY

twie przystąpiono do pierwszych badań pilotażowych. Zostały one przeprowadzone wśród nauczycieli różnych przedmiotów, pracujących w szkołach różnego typu. Do analiz włączono dane pochodzących od 80 nauczycieli (61 kobiet i 19 mężczyzn). Średnia wieku w badanej grupie wynosiła 39,2 roku $(S D=10,25)$; średni czas stażu w pracy nauczyciela wyniósł 14,4 lat $(S D=10,19)$.

\section{Uzyskane wyniki}

W celu sprawdzenia struktury czynnikowej thumaczonej metody wykonano eksploracyjną analizę czynnikową (EFA) metodą głównych składowych. Zgodnie z praktyką przyjętą przez autorki oryginalnej wersji skali, także w tej analizie zastosowano rotację ortogonalną Varimax. Wyznacznik macierzy korelacji osiągnął wartość bliską, ale różną od zera $(t=0,002)$, co oznacza, że znajdują się w niej stwierdzenia, które w oczekiwany sposób ze sobą korelują. Miara adekwatności doboru próby (KMO) była równa 0,777 , a test sferyczności Bartletta osiągnął wysoki poziom istotności $\left(\chi^{2}=470,19, d f=66, p<0,001\right)$, potwierdzając zasadność wykonania analizy czynnikowej (Wieczorkowska, Wierzbiński, 2005).

Tabela 1. Wyniki eksploracyjnej analizy czynnikowej ( EFA) dla I polskojęzycznej wersji TSES $(\mathrm{N}=80)$.

\begin{tabular}{ll} 
Treść pytania i jego numer & Czynnik \\
\cline { 2 - 3 } & $\frac{\mathrm{I}}{\mathrm{LC}} \frac{\mathrm{II}}{\mathrm{LC}} \frac{\mathrm{III}}{\mathrm{LC}}$ \\
\hline
\end{tabular}

W jakim stopniu potrafisz...

pomóc uczniom zdobyć przekonanie, że warto się uczyć? (4)

$\mathbf{0 , 8 3} \quad 0,20 \quad 0,18$

zaangażować rodziców w motywowanie ich dzieci do nauki i dobrej pracy na lekcji? (11)

$\mathbf{0 , 7 5} 0,03 \quad 0,29$

przekonać uczniów, że są zdolni odnosić sukcesy w szkole? (7)

$\mathbf{0 , 7 5} \quad 0,21 \quad 0,37$

motywować uczniów, którzy wykazują niskie zainteresowanie nauką i pracą na lekcji? (2)

$\mathbf{0 , 7 3} \quad 0,38 \quad 0,11$

uspokoić ucznia, który głośnym zachowaniem przeszkadza w prowadzeniu zajęć? (3)

$0,03 \quad \mathbf{0 , 7 8} \quad 0,26$

skutecznie reagować na niewłaściwe zachowania uczniów w klasie? (1) $\quad 0,23 \quad \mathbf{0 , 7 8} \quad 0,11$

sprawić, by uczniowie przestrzegali zasad obowiązujących w klasie? (6) $\quad 0,28 \quad 0, \mathbf{0 , 7 6} \quad 0,16$

z każdą klasą ustalić zasady obowiązujące na lekcji? (8)

$0,18 \quad \mathbf{0 , 6 5} \quad 0,40$

stosować różnorodność metod sprawdzania wiadomości i umiejętności uczniów? (9)

$0,28 \quad 0,25 \quad \mathbf{0 , 7 4}$

przedstawić uczniom alternatywne wytłumaczenie wówczas, gdy nie rozumieją podawanych treści? (10)

$0,24 \quad 0,14 \quad \mathbf{0 , 7 3}$


POLSKIE OPRACOWANIE KRÓTKIEJ WERSJI SKALI POCZUCIA SKUTECZNOŚCI NAUCZYCIELSKIEJ (TSES) TSHANNEN-MORAN I WOOLFOLK HOY

\begin{tabular}{|c|c|c|c|}
\hline formułować trafne i zrozumiałe dla uczniów pytania? (5) & 0,10 & 0,16 & $\mathbf{0 , 6 8}$ \\
\hline $\begin{array}{l}\text { stosować różnorodne formy i metody pracy z uczniami w Twojej kla- } \\
\text { sie? }{ }_{(12)}\end{array}$ & 0,32 & 0,27 & 0,67 \\
\hline Wartość własna & 5,54 & 1,34 & 1,06 \\
\hline Procent wyjaśnianej wariancji & 46,16 & 11,18 & 8,37 \\
\hline
\end{tabular}

Adnotacja. ŁC - ładunki czynnikowe. Wyróżniono ładunki czynnikowe przekraczające wartość 0,40 .

Opierając się na kryterium Kaisera, według którego za istotne uznaje się czynniki, których wartość własna jest większa od 1, w efekcie wykonanej analizy otrzymano trzy składowe wyjaśniające łącznie 66,21\% zmienności wyników. Macierz składowych rotowanych, ich wartości własne oraz procent wyjaśnianej wariancji przedstawiono w tabeli 1. Pierwsza składowa reprezentowana jest przez cztery pytania, których ładunki czynnikowe osiągają wysokie wartości w zakresie 0,83-0,73. Treść tych itemów odpowiada wymiarowi TSES, określanemu jako motywowanie. Drugi czynnik opiera się na kolejnych czterech pytaniach o ładunkach czynnikowych o wartościach $0,78-0,65$. Tematycznie odpowiada on dymensji odnoszącej się do poczucia przekonania w aspekcie kierowania klasą. Pozostałe cztery pytania, o ładunkach czynnikowych z przedziału $0,74-0,67$, składają się na czynnik reprezentujący wymiar nauczania. Każda z czterech pozycji testowych, wchodzących w skład danego czynnika, uzyskała ładunki zdecydowanie przekraczające rekomendowaną wartość 0,40 (Bedyńska, Cypryańska, 2007) oraz wyraźnie niższe wartości w pozostałych czynnikach. Struktura uzyskana na podstawie wstępnego badania jest zatem przejrzysta, jednoznacznie interpretowalna i odpowiada strukturze wersji oryginalnej.

Kolejnym etapem prowadzonych analiz było ustalenie dla uzyskanych wymiarów współczynników rzetelności wewnętrznej $\alpha$ Cronbacha. W przypadku podskal wartości tej statystyki wynosiły $0,84-0,79$, natomiast dla wyniku ogólnego $\alpha=0,89$, co świadczy o satysfakcjonującym poziomie rzetelności narzędzia.

Rezultaty tych badań oraz aktualna postać skali zostały poddane ponownej dyskusji w gronie psychologów. Podjęto wówczas decyzję o modyfikacji treściowej trzech pozycji kwestionariusza (itemy nr: 3, 7 i 9) tak, aby ich brzmienie zyskało bardziej spójną i bliższą oryginałowi formę. Po wprowadzeniu poprawek językowych wykonano drugie badanie pilotażowe wśród nauczycieli różnych przedmiotów, pracujących w szkołach różnego typu. Do analiz statystycznych zakwalifikowano dane pochodzące od 301 pedagogów (246 kobiet, 48 mężczyzn, 7 osób nie zdeklarowało swojej płci). Średnia wieku w badanej grupie wynosiła 41,7 


\section{POLSKIE OPRACOWANIE KRÓTKIEJ WERSJI SKALI POCZUCIA SKUTECZNOŚCI}

NAUCZYCIELSKIEJ (TSES) TSHANNEN-MORAN I WOOLFOLK HOY

roku $(S D=9,54)$; średni czas stażu w zawodzie nauczyciela wyniósł 16,5 roku $(S D=9,80)$. W celu sprawdzenia struktury czynnikowej przygotowanego kwestionariusza wykonano analizę składowych głównych z rotacją Varimax. Wyznacznik macierzy korelacji osiągnął wartość $t=0,009$, co oznacza, że znajdują się w niej skorelowane stwierdzenia, które mogą się ze sobą grupować, tworząc czynniki. Miara KMO była równa 0,868, a test sferyczności Bartletta osiągnął wysoki poziom istotności $\left(\chi^{2}=1402,12, d f=66, p<0,001\right)$, potwierdzając zasadność wykonywanej analizy.

Tabela 2. Wyniki eksploracyjnej analizy czynnikowej (EFA) dla II polskojęzycznej wersji TSES; $\mathrm{N}=301$ (w nawiasach struktura czynnikowa oryginalnej wersji TSES; $\mathrm{N}=410$ ).

\begin{tabular}{|c|c|c|c|}
\hline \multirow{3}{*}{ Treść pytania i jego numer } & \multicolumn{3}{|c|}{ Czynnik } \\
\hline & $\mathrm{I}$ & II & III \\
\hline & $\mathrm{LC}$ & $\mathrm{LC}$ & $\mathrm{LC}$ \\
\hline \multicolumn{4}{|l|}{ W jakim stopniu potrafisz... } \\
\hline przekonać uczniów, że mogą odnosić sukcesy w szkole? (7) & $\begin{array}{c}\mathbf{0 , 7 7} \\
(\mathbf{0 , 7 5})\end{array}$ & 0,14 & 0,28 \\
\hline pomóc uczniom zdobyć przekonanie, że warto się uczyć? (4) & $\begin{array}{c}\mathbf{0 , 7 6} \\
(\mathbf{0 , 6 9})\end{array}$ & 0,19 & 0,22 \\
\hline $\begin{array}{l}\text { motywować uczniów, którzy wykazują niskie zaintereso- } \\
\text { wanie nauką i pracą na lekcji? (2) }\end{array}$ & $\begin{array}{c}\mathbf{0 , 7 5} \\
(\mathbf{0 , 6 4})\end{array}$ & 0,22 & 0,14 \\
\hline $\begin{array}{l}\text { zaangażować rodziców w motywowanie ich dzieci do nauki } \\
\text { i dobrej pracy na lekcji? }\end{array}$ & $\begin{array}{c}0,69 \\
(0,62)\end{array}$ & 0,24 & 0,16 \\
\hline uspokoić ucznia, który rozrabia lub hałasuje? (3) & 0,16 & $\begin{array}{c}\mathbf{0 , 8 4} \\
(\mathbf{0 , 6 3})\end{array}$ & 0,05 \\
\hline $\begin{array}{l}\text { skutecznie reagować na niewłaściwe zachowania uczniów } \\
\text { w klasie? }\end{array}$ & 0,24 & $\begin{array}{c}\mathbf{0 , 8 0} \\
(\mathbf{0 , 8 3})\end{array}$ & 0,11 \\
\hline $\begin{array}{l}\text { sprawić, by uczniowie przestrzegali zasad obowiązujących } \\
\text { w klasie? (6) }\end{array}$ & 0,24 & $\begin{array}{c}0,71 \\
(0,66)\end{array}$ & 0,19 \\
\hline z każdą klasą ustalić zasady obowiązujące na lekcji? (8) & 0,13 & $\begin{array}{c}\mathbf{0 , 5 9} \\
(\mathbf{0 , 6 1})\end{array}$ & $\mathbf{0 , 4 2}$ \\
\hline $\begin{array}{l}\text { przedstawić uczniom alternatywne wytłumaczenie wów- } \\
\text { czas, gdy nie rozumieją podawanych treści? }{ }_{(10)}\end{array}$ & 0,10 & 0,16 & $\begin{array}{r}\mathbf{0 , 7 9} \\
(\mathbf{0 , 7 3 )}\end{array}$ \\
\hline formułować trafne i zrozumiałe dla uczniów pytania? (5) & 0,15 & 0,15 & $\begin{array}{r}\mathbf{0 , 7 3} \\
(\mathbf{0 , 6 3})\end{array}$ \\
\hline $\begin{array}{l}\text { stosować różnorodne metody sprawdzania wiadomości i } \\
\text { umiejętności uczniów? }\end{array}$ & 0,31 & 0,12 & $\begin{array}{c}\mathbf{0 , 7 0} \\
(\mathbf{0 , 7 5})\end{array}$ \\
\hline $\begin{array}{l}\text { stosować różnorodne formy i metody pracy z uczniami w } \\
\text { Twojej klasie? (12) }\end{array}$ & $\mathbf{0 , 4 3}$ & 0,11 & $\begin{array}{c}\mathbf{0 , 6 1} \\
(\mathbf{0 , 7 3})\end{array}$ \\
\hline \multicolumn{2}{|l|}{ Wartość własna $\begin{array}{c}5,04 \\
(1,11)\end{array}$} & $\begin{array}{c}1,40 \\
(5,68)\end{array}$ & $\begin{array}{c}1,12 \\
(1,51)\end{array}$ \\
\hline \multicolumn{2}{|c|}{ Procent wyjaśnianej wariancji41,98 } & 11,66 & 9,37 \\
\hline
\end{tabular}


POLSKIE OPRACOWANIE KRÓTKIEJ WERSJI SKALI POCZUCIA SKUTECZNOŚCI NAUCZYCIELSKIEJ (TSES) TSHANNEN-MORAN I WOOLFOLK HOY

\section{$(9,21)$}

$(47,30)$

$(12,59)$

Adnotacja. ŁC - ładunki czynnikowe. Wyróżniono ładunki czynnikowe przekraczające wartość 0,40. Wyniki EFA dla oryginalnej wersji TSES podano za: Tschannen-Moran, Woolfolk Hoy, 2001, s. 800.

Zgodnie z kryterium Kaisera wyodrębnione zostały trzy składowe wyjaśniające łącznie 63,01\% wariancji. Macierz składowych rotowanych, ich wartości własne oraz procent wyjaśnianej wariancji przedstawiono w tabeli 2. Biorąc pod uwagę ładunki czynnikowe można stwierdzić, że każdy z czynników reprezentowany jest przez cztery pytania, pozostające ze sobą W zgodności tematycznej. Uzasadnia to przypisanie poszczególnym składowym nazw analogicznych do podskal oryginalnej wersji testu: motywowanie (wartości ładunków czynnikowych w zakresie $0,77-0,69)$, kierowanie $(0,84-0,59)$ oraz nauczanie $(0,79-0,61)$. Każda z pozycji testowych, wchodzących w skład danego czynnika, uzyskała ładunki przekraczające pożądaną wartość 0,40 oraz wyraźnie niższe wartości w pozostałych czynnikach. Pytania nr 8 i nr 12 osiągnęły natomiast współczynniki o wartości powyżej 0,40 w ramach dwóch czynników. Oznacza to, że ich teść nienajlepiej różnicuje badane aspekty pracy nauczyciela. Wyższa wartość ładunku czynnikowego wskazuje jednak znacznie silniejsze powiązanie tych itemów ze skalami odpowiadającymi im w oryginalnej wersji testu.

W tabeli 2 umieszczono także (w nawiasach) udostępnione przez Tschannen-Moran i Woolfolk Hoy (2001) wyniki analizy czynnikowej na danych z próby 410 nauczycieli amerykańskich. Procent wyjaśnionej wariancji oraz wartości ładunków czynnikowych w ramach wyłonionych składowych głównych w oryginalnej oraz drugiej polskojęzycznej wersji TSES można uznać za zbliżone do siebie, z tym że różna jest kolejność uzyskanych czynników.

W tabeli 3 przedstawiono wzajemne korelacje między poszczególnymi wymiarami kwestionariusza. Wzajemny związek pomiędzy podskalami jest umiarkowany, natomiast skorelowanie każdej z dymensji poczucia skuteczności z wynikiem ogólnym skali osiąga poziom wysoki.

Tabela 3. Korelacje r-Pearsona między wymiarami polskojęzycznej wersji TSES.

\begin{tabular}{lcccc}
\hline \multicolumn{1}{c}{ Wymiary TSES } & SM & SK & SN & $\begin{array}{c}\text { Wynik } \\
\text { ogólny }\end{array}$ \\
\hline SM: Motywowanie & 1 & & & \\
SK: Kierowanie & 0,52 & 1 & & \\
SN: Nauczanie & 0,56 & 0,46 & 1
\end{tabular}


POLSKIE OPRACOWANIE KRÓTKIEJ WERSJI SKALI POCZUCIA SKUTECZNOŚCI NAUCZYCIELSKIEJ (TSES) TSHANNEN-MORAN I WOOLFOLK HOY

\begin{tabular}{lllll}
\hline Wynik ogólny & 0,86 & 0,80 & 0,80 & 1 \\
\hline Achotacja. Wszystke koreacje na pozionie
\end{tabular}

Adnotacja. Wszystkie korelacje na poziomie istotności $p<0,001$.

Analiza statystyk opisowych dla poszczególnych dymensji TSES wskazuje, że nauczyciele badani polską wersją kwestionariusza, w porównaniu ze swoimi kolegami w Stanach Zjednoczonych, są bardziej zgodni w określaniu swojego poczucia skuteczności (patrz tab. 4).

Ponadto wyżej oceniają przekonanie o własnej zdolności do kierowania klasą, natomiast niżej postrzegają swoje umiejętności związane z motywowaniem uczniów do efektywnej pracy w szkole. Średni poziom poczucia własnej skuteczności w nauczaniu uczniów jest zbliżony do siebie w próbach polskich i amerykańskiej.

Tabela 4. Porównanie statystyk opisowych i współczynników rzetelności wewnętrznej $\alpha$ Cronbacha polskojęzycznych i oryginalnej wersji TSES.

\begin{tabular}{|c|c|c|c|c|c|c|c|c|c|c|c|}
\hline \multirow{3}{*}{ Wersje TSES } & \multirow{3}{*}{$N$} & \multicolumn{10}{|c|}{ Wymiary TSES } \\
\hline & & \multicolumn{2}{|c|}{$\begin{array}{c}\text { SM: } \\
\text { Motywowanie }\end{array}$} & \multicolumn{3}{|c|}{$\begin{array}{c}\text { SM: } \\
\text { Kierowanie }\end{array}$} & \multicolumn{3}{|c|}{ SM: Nauczanie } & \multicolumn{2}{|c|}{ Wynik ogólny } \\
\hline & & $M \quad S D$ & $\alpha$ & $M$ & $S D$ & $\alpha$ & $M$ & $S D$ & $\alpha$ & $M S D$ & $\alpha$ \\
\hline $\begin{array}{l}\text { Wersja polskoję- } \\
\text { zyczna I }\end{array}$ & 80 & $6,4 \quad 1,19$ & 0,84 & 7,2 & 0,99 & 0,81 & 7,2 & 0,96 & 0,79 & $6,90,88$ & 0,89 \\
\hline $\begin{array}{l}\text { Wersja polskoję- } \\
\text { zyczna II }\end{array}$ & 301 & $6,61,03$ & 0,81 & 7,3 & 0,93 & 0,80 & 7,6 & 0,83 & 0,77 & $7,20,76$ & 0,87 \\
\hline Wersja oryginalna $^{a}$ & 410 & $7,2 \quad 1,2$ & 0,81 & 6,7 & 1,2 & 0,86 & 7,3 & 1,2 & 0,86 & $7,1 \quad 0,98$ & 0,90 \\
\hline
\end{tabular}

${ }^{a}$ Statystyki oryginalnej wersji TSES podano za: Tschannen-Moran, Woolfolk Hoy, 2001, s. 800.

W wyniku kolejnych analiz drugiej polskojęzycznej wersji TSES ustalono dla tego narzędzia współczynniki rzetelności wewnętrznej $\alpha$ Cronbacha. Dla poszczególnych wymiarów osiągnęły one następujące wartości: motywowanie $\alpha=0,81$, kierowanie $\alpha=0,80$, nauczanie $\alpha=0,77$ oraz wynik ogólny $\alpha=0,87$. Tabela 4 daje możliwość porównania poziomu zgodności wewnętrznej kwestionariusza obliczonej w dwóch badaniach pilotażowych wersji polskiej oraz wartości ustalonych dla wersji oryginalnej. Skala amerykańska charakteryzuje się wyraźnie wyższymi wartościami współczynnika $\alpha$ Cronbacha dla wymiarów kierowanie i nauczanie. Poziom rzetelności skal wersji polskiej należy jednak uznać za satysfakcjonujący.

Badając właściwości psychometryczne polskojęzycznej skali TSES przeprowadzono także ocenę mocy dyskryminacyjnej poszczególnych pozycji testu. Posłużono się w tym celu współczynnikiem korelacji punktowo-czteropolowej między każdym pytaniem kwestionariusza 
POLSKIE OPRACOWANIE KRÓTKIEJ WERSJI SKALI POCZUCIA SKUTECZNOŚCI NAUCZYCIELSKIEJ (TSES) TSHANNEN-MORAN I WOOLFOLK HOY

a jego wynikiem ogólnym. Wcześniej dokonano koniecznego w tej procedurze wyodrębnienia osób o wysokich i niskich wynikach w globalnym poczuciu skuteczności nauczycielskiej (dwie grupy po 26,6\% badanych) oraz dychotomizacji odpowiedzi dla każdego itemu (Brzeziński, 1978). W tabeli 5 przedstawiono wartości współczynnika korelacji $\varphi$ Yule’a dla badanych powiązań. Poszczególne itemy zostały umieszczone w kolumnach odpowiadających wymiarom TSES. Wszystkie pytania skali okazały się istotnie korelować z wynikiem ogólnym, a siła tego związku osiąga poziom co najmniej umiarkowany. Pytaniem o najwyższej mocy dyskryminacyjnej okazał się item $\mathrm{nr} 2$, natomiast najniższą, ale ciągle satysfakcjonującą moc dyskryminacyjną posiadają pozycje nr 5 i 10, reprezentujące poczucie skuteczności nauczycieli w aspekcie nauczania.

Tabela 5. Moce dyskryminacyjne pozycji testowych polskojęzycznej wersji TSES (N = 301).

\begin{tabular}{|c|c|c|c|c|c|}
\hline \multicolumn{6}{|c|}{ Wymiary TSES } \\
\hline \multicolumn{2}{|c|}{ SM: Motywowanie } & \multicolumn{2}{|c|}{ SM: Kierowanie } & \multicolumn{2}{|c|}{ SM: Nauczanie } \\
\hline Item & $\varphi$ & Item & $\varphi$ & Item & $\varphi$ \\
\hline 2 & 0,78 & 1 & 0,62 & 5 & 0,49 \\
\hline 4 & 0,65 & 3 & 0,68 & 9 & 0,54 \\
\hline 7 & 0,68 & 6 & 0,69 & 10 & 0,44 \\
\hline 11 & 0,65 & 8 & 0,57 & 12 & 0,73 \\
\hline
\end{tabular}

Adnotacja. $\varphi$ - współczynnik korelacji punktowo-czteropolowej między itemem kwestionariusza a jego wynikiem ogólnym (phi Yule'a ). Wszystkie korelacje na poziomie $p<0,001$.

Trafność teoretyczna polskiego opracowania skali została również poddana weryfikacji za pomocą konfirmacyjnej analizy czynnikowej (CFA). Oszacowania parametrów modelu dokonano metodą największej wiarygodności ML (maximum likelihood). Chociaż jest ona wrażliwa na odstępstwa od wielowymiarowego rozkładu normalnego zmiennych obserwowalnych oraz wymaga dużych prób, pozostaje najczęściej stosowaną metodą estymacji (Bedyńska, Książek, 2012).

Tradycyjnie cytowanym wskaźnikiem dopasowania modelu do danych jest wartość statystyki $\chi^{2}$. Brak istotności dla wyniku tego testu na poziomie $p>0,05$ oznacza, że reszty standaryzowane macierzy teoretycznej i empirycznej nie różnią się między sobą, czyli sprawdzany przez badacza model można uznać za trafny. Niestety posługiwanie się tym testem wymaga spełnienia warunku wielowymiarowego rozkładu normalnego i dużej liczebności próby. Z tego względu, prócz statystyki $\chi^{2}$, stosowane są inne miary dopasowania modelu do danych. Jedną z nich jest miara $\chi^{2} / d f$, która - według konserwatywnego kryterium - gdy jest mniejsza niż 2 
POLSKIE OPRACOWANIE KRÓTKIEJ WERSJI SKALI POCZUCIA SKUTECZNOŚCI NAUCZYCIELSKIEJ (TSES) TSHANNEN-MORAN I WOOLFOLK HOY

$\overline{\text { wskazuje na dobre dopasowanie modelu. Wedle kryterium bardziej liberalnego założony model }}$ uważany jest za akceptowalny gdy wartość tego ilorazu jest mniejsza lub równa 4, a nawet 5 . Spośród innych miar dopasowania wymienia się często wskaźnik dobroci dopasowania GFI (goodness of fit index) oraz skorygowany wskaźnik dobroci dopasowania AGFI (adjusted goodness of fit index), których wartości powyżej 0,90 traktowane są zwykle jako potwierdzenie trafności modelu. Według opinii ekspertów, w grupie różnych miar dopasowania, największą rangę posiada pierwiastek średniokwadratowego błędu aproksymacji RMSEA (root mean square error of approximation). Jego wartości mniejsze od 0,05 świadczą o dobrym dopasowaniu modelu do danych empirycznych, wartości mniejsze od 0,08 uważane są za wskaźnik przyzwoitego dopasowania, natomiast większe od 0,1 stanowią podstawę do odrzucenia modelu (Januszewski, 2011).

$\mathrm{W}$ analizowanym przypadku funkcja rozbieżności $\chi^{2}=151,51 ; d f=51 ; p<0,001$. Chociaż test ten okazał się istotny statystycznie, sugerując nieadekwatność badanego modelu, zgonie ze wcześniej poczynionymi uwagami, skoncentrowano się na pozostałych miarach dopasowania. Iloraz $\chi^{2} / d f=2,97$, co pozwala, według bardziej liberalnych kryteriów oceny, na akceptację testowanego modelu. Miara GFI wyniosła 0,92, przekraczając tym samym wymaganą wartość progową 0,90, natomiast wskaźnik AGFI był bliski tej wartości, osiągając wynik 0,88. Punkt estymowany dla RMSEA równał się 0,081, natomiast $90 \%$ przedział ufności dla tej miary wynosił 0,066-0,096. Wartości zastosowane w analizie testów wskazują, że założona struktura polskojęzycznej wersji TSES nie spełnia konserwatywnych warunków dobrego dopasowania do empirycznej macierzy kowariancji. Uzyskane wartości pozwalają jednak uznać model za dopuszczalny w świetle bardziej liberalnych kryteriów przyjmowanych w środowisku badaczy. Należy zaznaczyć, że otrzymane wyniki pochodzą z konfirmacji modelu, w ramach którego nie wprowadzano dodatkowej modyfikacji w odniesieniu do skorelowania błędów. Jej wprowadzenie wiąże się ze zmianą wstępnych założeń teoretycznych, ale znacząco poprawia wskaźniki dopasowania modelu. Dla przykładu, wprowadzenie założenia o korelacji jedynie w przypadku dwóch par błędów zmiennych jawnych skali, pozwoliło uzyskać następujące miary rozbieżności: $\chi^{2} / d f=2,24 ;$ GFI = 0,94; AGFI = 0,91; RMSEA = 0,064 (0,048-0,080). Wartości te wyraźnie zbliżają się do spełnienia bardziej restrykcyjnych kryteriów formułowanych dla modeli dobrze dopasowanych.

Tabela 6. Wyniki konfirmacyjnej analizy czynnikowej (CFA) dla wersji TSES testowanych w różnych próbach. 
POLSKIE OPRACOWANIE KRÓTKIEJ WERSJI SKALI POCZUCIA SKUTECZNOŚCI NAUCZYCIELSKIEJ (TSES) TSHANNEN-MORAN I WOOLFOLK HOY

\begin{tabular}{|c|c|c|c|c|c|c|}
\hline \multirow{2}{*}{ Próba } & \multirow{2}{*}{$N$} & \multicolumn{2}{|c|}{ Model bez modyfikacji } & \multicolumn{3}{|c|}{ Model zmodyfikowany } \\
\hline & & $\chi^{2} / d f$ & RMSEA & $\mathrm{ZK}$ & $\chi^{2} / d f$ & RMSEA \\
\hline Polska & 301 & 2,97 & 0,081 & $\delta_{5,10} \delta_{11,12}$ & 2,24 & 0,064 \\
\hline Kanada I & 210 & 1,77 & 0,061 & $\delta_{11,12}$ & 1,55 & 0,051 \\
\hline Kanada II & 255 & 2,12 & 0,066 & $\delta_{11,12}$ & 1,68 & 0,052 \\
\hline Cypr & 210 & 3,28 & 0,105 & $\delta_{5,6} \delta_{5,10}$ & 2,59 & 0,087 \\
\hline Korea & 153 & 3,71 & 0,134 & $\delta_{11,12} \delta_{9,11}$ & 2,66 & 0,104 \\
\hline Stany Zjednoczone & 137 & 1,38 & 0,053 & - & - & - \\
\hline Singapur & 247 & 2,38 & 0,075 & $\delta_{11,12}$ & 2,00 & 0,064 \\
\hline
\end{tabular}

Adnotacja. ZK - założone korelacje między błędami itemów o podanych numerach. Wyniki weryfikacji zagranicznych wersji TSES podano za: Klassen i in., 2009, s. 71.

W tabeli 6 przedstawiono wyniki wybranych testów rozbieżności w konfirmacyjnej analizie czynnikowej wykonanej dla polskojęzycznego opracowania TSES oraz wersji weryfikowanych w badaniach Klassena i in. (2009). Zwracając uwagę na parametry kwestionariuszy opracowanych w innym języku niż angielski (próba z Korei i Cypru), można dostrzec, że polskie tłumaczenie skali uzyskało znacznie lepsze od nich wskaźniki dopasowania. Są one natomiast wyraźnie gorsze od miar adekwatności modelu wyliczonych w próbach nauczycieli wykonujących swój zawód w Stanach Zjednoczonych i Kanadzie, zbliżone zaś do anglojęzycznej wersji kwestionariusza weryfikowanego wśród pedagogów pracujących w Singapurze.

Prace związane z opracowaniem polskiej wersji kwestionariusza TSES zostały zakończone przetłumaczeniem skali z języka polskiego na język angielski (back translation). Czynność ta została dokonana przez nauczyciela polskiego pochodzenia, pracującego w szkole amerykańskiej. Rezultat tej pracy wraz z opisem procedury opracowania polskiej wersji TSES, danymi dotyczącymi jej struktury czynnikowej oraz wyliczone wskaźniki psychometryczne przesłano do profesor Tschannen-Moran, autorki oryginalnej wersji kwestionariusza. Po zapoznaniu się z przekazaną dokumentacją wyraziła ona akceptację dla polskiej wersji testu.

Polska wersja kwestionariusza TSES została wykorzystana w badaniach funkcjonowania zawodowego przeprowadzonych wśród nauczycieli religii. Grupa ta składała się z 424 osób (287 kobiet), wykonujących swoją pracę w polskich szkołach różnego szczebla edukacji. Średnia wieku wśród kobiet wynosiła $M=42,6(S D=7,44)$, wśród mężczyzn zaś $M=36,4(S D=$ $8,05)$. Prezentowane w tym punkcie wyniki dotyczą korelacji przekonania o własnej skuteczności nauczycielskiej z poziomem wypalenia i zaangażowania w pracę. Należy je traktować jako 
POLSKIE OPRACOWANIE KRÓTKIEJ WERSJI SKALI POCZUCIA SKUTECZNOŚCI NAUCZYCIELSKIEJ (TSES) TSHANNEN-MORAN I WOOLFOLK HOY

przyczynek do weryfikacji trafności zbieżnej i rozbieżnej dla przetłumaczonej skali.

Wypalenie zawodowe zostało ujęte zgodnie z propozycją Maslach (1982) jako konstrukt wielowymiarowy, na który składają się wyczerpanie emocjonalne, depersonalizacja oraz obniżone poczucie dokonań osobistych. Pomiaru poszczególnych dymensji dokonano przy pomocy polskiej wersji kwestionariusza Maslach Burnout Inventory (MBI), posiadającego dobre właściwości psychometryczne (Pasikowski, 2010; Tucholska, 2009). Rezultaty badań, zgodnie ujawniają negatywny związek między przekonaniem o własnej skuteczności w pracy nauczycielskiej a wypaleniem pedagogów. Ze względu na podobną płaszczyznę teoretyczną najbardziej zrozumiała jest korelacja między poczuciem własnej skuteczności a doświadczanym w pracy poziomem osiągnięć osobistych (Schwarzer, Hallum, 2008; Skaalvik, Skaalvik, 2007). Wyniki badań własnych z użyciem polskiej wersji TSES potwierdzają te współzależności (patrz tab. 7).

Tabela 7. Korelacje r-Pearsona między wymiarami polskojęzycznej wersji TSES a dymensjami wypalenia zawodowego i zaangażowania w pracę $(\mathrm{N}=424)$.

\begin{tabular}{lcccccccc}
\hline \multirow{2}{*}{ Wymiary TSES } & \multicolumn{3}{c}{ Wymiary wypalenia } & & \multicolumn{3}{c}{ Wymiary zaangażowania } \\
\cline { 2 - 3 } & EW & DP & BO & & W & PSW & ZBS \\
\hline SM: Motywowanie & $-0,32$ & $-0,39$ & $-0,56$ & & 0,54 & 0,50 & 0,38 \\
SK: Kierowanie & $-0,40$ & $-0,39$ & $-0,59$ & & 0,51 & 0,44 & 0,26 \\
SN: Nauczanie & $-0,33$ & $-0,41$ & $-0,51$ & & 0,52 & 0,47 & 0,34 \\
Wynik ogólny & $-0,39$ & $-0,44$ & $-0,62$ & & 0,58 & 0,52 & 0,36 \\
\hline
\end{tabular}

Adnotacja. EW - emocjonalne wyczerpanie; DP - depersonalizacja; $\mathrm{BO}$ - brak poczucia osiągnięć osobistych; W - wigor; PSW - poświęcenie; ZBS - zaabsorbowanie. Wszystkie korelacje na poziomie istotności $p<0,001$.

Emocjonalne wyczerpanie (EW) koreluje ujemnie z poczuciem własnej skuteczności w zawodzie nauczyciela, zwłaszcza w odniesieniu do czynności polegających na kierowaniu klasą (SK), czyli ustalaniu reguł zachowania uczniów i ich dyscyplinowaniu. Biorąc pod uwagę fakt, że wymiar emocjonalnego wyczerpania jest szczególnie powiązany ze stresem, jaki doświadczają pedagodzy w związku z niewłaściwymi zachowaniami uczniów (Tucholska, 2009), silne przekonanie o własnej skuteczności w obszarze kierowania klasą stanowi ważny zasób nauczycielski, chroniący przed opisywanym symptomem wypalenia. Negatywny związek zachodzi także między poczuciem skuteczności a przedmiotowym traktowaniem uczniów (DP) oraz obniżonym poczuciem dokonań osobistych (BO). Ten ostatni wymiar wypalenia ujawnia największe powiązanie z przekonaniem o własnej skuteczności, co potwierdza duże podobień- 
POLSKIE OPRACOWANIE KRÓTKIEJ WERSJI SKALI POCZUCIA SKUTECZNOŚCI NAUCZYCIELSKIEJ (TSES) TSHANNEN-MORAN I WOOLFOLK HOY

stwo treściowe obu konstruktów ${ }^{4}$.

W prezentowanych badaniach zaangażowanie zostało ujęte, jako ,pozytywny, dający poczucie spełnienia, związany z pracą stan umysłu, który charakteryzuje się wigorem, poświęceniem i zaabsorbowaniem" (Schaufeli, Salanova, González-Romá, Bakker, 2002, s. 74). Zmienna ta została oszacowana przy pomocy polskiej, 17 - itemowej wersji kwestionariusza Utrecht Work Engagement Scale (UWES). Narzędzie to posiada dobre właściwości psychometryczne (Schaufeli, Bakker, 2003). Uzyskane w badaniach własnych dodatnie korelacje między poszczególnymi dymensjami zaangażowania w pracę oraz wymiarami poczucia skuteczności zawodowej (patrz. tab. 7) potwierdzają współzależności zaobserwowane przez innych autorów (Tschannen-Moran, Woolfolk Hoy, 2001; Xanthopoulou, Bakker, Demerouti, Schaufeli, 2007). Nauczyciele charakteryzujący się silnym przekonaniem o własnej skuteczności wykazują więcej entuzjazmu podczas wykonywania swoich obowiązków oraz potrafią zdobywać się na większe poświecenie zawodowe. Wyniki badań własnych potwierdzają także, że zaabsorbowanie w pracę, które oddaje stan pochłonięcia pracownika przez wykonywane zadania, spośród trzech wymiarów zaangażowania, ujawnia najsłabszy związek z przekonaniem o własnej skuteczności.

\section{Dyskusja}

Opracowana przez Tschannen-Moran i Woolfolk Hoy (2001) skala do pomiaru poczucia skuteczności nauczycielskiej jest narzędziem dobrze wpisanym w teoretyczne założenia społeczno-poznawczej teorii Bandury (1977). Daje ona możliwość oszacowanie ważnego zasobu, umożliwiającego nauczycielom efektywne wykonywanie swoich obowiązków zawodowych oraz chroniącego ich przed negatywnymi konsekwencjami stresu. Polska wersja tej skali odzwierciedla trójczynnikową strukturę oryginału, chociaż dwie pozycje testowe nienajlepiej różnicują badane aspekty pracy pedagoga. Pomimo tej słabości kwestionariusz posiada satysfakcjonujące właściwości psychometryczne, a wyniki badań przeprowadzonych z użyciem tej skali, można uznać za wstępne potwierdzenie jej trafności zbieżnej i rozbieżnej. Chociaż wskazane byłoby prowadzenie dalszych prac związanych z weryfikacją polskiej wersji

\footnotetext{
${ }^{4}$ Według nowej definicji wypalenia, uwzględniającej występowanie tego zjawiska w różnych, nie tylko pomocowych zawodach, wymiar opisany poprzednio jako obniżone poczucie dokonań osobistych został zastąpiony określeniem wskazującym na utratę zaufania pracownika do własnych umiejętności lub po prostu brakiem skuteczności (Maslach, Leiter, 2011).
} 
POLSKIE OPRACOWANIE KRÓTKIEJ WERSJI SKALI POCZUCIA SKUTECZNOŚCI NAUCZYCIELSKIEJ (TSES) TSHANNEN-MORAN I WOOLFOLK HOY

tego narzędzia, a nawet udoskonaleniem niektórych pozycji testowych, skalę można uznać za miarę na tyle rzetelną, aby już na tym etapie adaptacji móc ją stosować w badaniach poświęconych pracy nauczyciela. 


\section{Literatura cytowana}

Bandura, A. (1977). Self-efficacy: Toward a unifying theory of behavioral change.Psychological Review, 84(2), 191-215.

Bandura, A. (1997). Self-efficacy: The exercise of control. New York: W. H. Freeman.

Bedyńska, S., Cypryańska, M. (2007). Zaawansowane sposoby tworzenia wskaźników: Zastosowanie analizy czynnikowej oraz analizy rzetelności pozycji. W: S. Bedyńska, A. Brzezicka (red.), Statystyczny drogowskaz. Praktyczny poradnik analizy danych wnaukach społecznych na przyktadach z psychologii (s. 134-161). Warszawa: Wyd. SWPS „Akademika”.

Bedyńska, S., Książek, M. (2012). Statystyczny drogowskaz 3. Praktyczny przewodnik wykorzystania modeli regresji oraz równań strukturalnych. Warszawa: Wyd. Akademickie „Sedno”.

Brzeziński, J. (1978). Etapy konstruowania kwestionariusza osobowości. W: W. Sanocki (red.), Kwestionariusze osobowości w psychologii (s. 269-312). Warszawa: PWN.

Drwal, Ł. (1995). Adaptacja kwestionariuszy osobowości. Wybrane zagadnienia i techniki. Warszawa: PWN.

Fives, H., Buehl, M. M. (2010). Examining the factor structure of the teachers' sense of efficacy scale. The Journal of Experimental Education, 78(1), 118-134.

Januszewski, A. (2011). Modele równań strukturalnych w metodologii badań psychologicznych. Problematyka przyczynowości w modelach strukturalnych i dopuszczalność modeli. W: O. Gorbaniuk, B. Kostrubiec-Wojtachnio, D. Musiał, M. Wiechetek, A. Błachnio, A. Przepiórka (red.), Studia z Psychologii w KUL (t. 17, s. 213-245). Lublin: Wyd. KUL.

Klassen, R. M., Bong, M., Usher, E. L., Chong, W., Huan, V. S., Wong, I. F., Georgiou, T. (2009). Exploring the validity of a teachers' self-efficacy scale in five countries. Contemporary Educational Psychology, 34(1), 67-76.

Klassen, R. M., Chiu, M. M. (2011). The occupational commitment and intention to quit of practicing and pre-service teachers: Influence of self-efficacy, job stress, and teaching context. Contemporary Educational Psychology, 36(2), 114-129.

Maslach, C. (1982). Understanding burnout: Definitional issues in analyzing a complex phenomenon. W: W. S. Paine (red.), Job stress and burnout (s. 29-40). Beverly Hills, CA: Sage.

Maslach, C., Leiter, M. (2011). Prawda o wypaleniu zawodowym. Co robić ze stresem w organizacji. Warszawa: PWN.

Pasikowski, T. (2010). Polska adaptacja kwestionariusza Maslach Burnout Inventory. W: H. Sęk (red.), Wypalenie zawodowe. Przyczyny $i$ zapobieganie (s. 135-148). Warszawa: PWN. 
Schaufeli, W. B., Salanova, M., González-Romá, V., Bakker, A. B. (2002). The measurement of engagement and burnout: A two sample confirmatory factor analytic approach. Journal of Happiness Studies, 3(1), 71-92.

Schaufeli, W. B., Bakker, A. B. (2003). The Utrecht Work Engagement Scale (UWES). Test manual. Utrecht: Department of Social \& Organizational Psychology.

Schwarzer, R., Hallum, S. (2008). Perceived teacher self-efficacy as a predictor of job stress and burnout: Mediation analyses. Applied Psychology: An International Review, 57(S), 152-171.

Skaalvik, E. M., Skaalvik, S. (2007). Dimensions of teacher self-efficacy and relations with strain factors, perceived collective teacher efficacy, and teacher burnout. Journal of Educational Psychology, 99(3), 611-625.

Tschannen-Moran, M., Woolfolk Hoy, A. (2001). Teacher efficacy: Capturing an elusive construct. Teaching and Teacher Education, 17(7), 783-805.

Tucholska, S. (2009). Wypalenie zawodowe u nauczycieli. Psychologiczna analiza zjawiska i jego osobowościowych uwarunkowań (wyd. 2). Lublin: Wyd. KUL.

Wieczorkowska, G., Wierzbiński, J. (2005). Badania sondażowe $i$ eksperymentalne. Wybrane zagadnienia. Warszawa: Wyd. Naukowe Wydziału Zarządzania Uniwersytetu Warszawskiego.

Xanthopoulou, D., Bakker, A. B., Demerouti, E., Schaufeli, W. B. (2007). The role of personal resources in the job demands-resources model. International Journal of Stress Management, 14(2), 121-141. 